\title{
Pemberdayaan Masyarakat Kayubulan Melalui Implementasi Teknologi Pengolahan Eceng Gondok dan Sedimen Danau Limboto
}

\author{
Yuszda K. Salimi ${ }^{1 *}$, Yuliyanti Kadir ${ }^{2}$, Julhim S. Tangio ${ }^{1}$ \\ 1 Jurusan Kimia, FMIPA, Universitas Negeri Gorontalo \\ 2Jurusan Teknik Sipil, FT, Universitas Negeri Gorontalo \\ email: yuszda.salimi@ung.ac.id
}

\begin{abstract}
ABSTRAK
Laju sedimentasi dari beberapa sungai yang bermuara di danau Limboto semakin tinggi sehingga menyebabkan pendangkalan. Pertumbuhan eceng gondok yang sangat cepat menutupi permukaan danau menyebabkan perubahan ekosistem danau dan kerugian finansial bagi nelayan lokal. Program Kuliah Kerja Nyata Pembelajaran Pemberdayaan Masyarakat (KKN PPM) di kelurahan Kayubulan bertujuan untuk mengedukasi masyarakat melalui implementasi teknologi pengolahan eceng gondok dan sedimen danau Limboto. Kegiatan pemberdayaan masyarakat melalui 5 (lima) tahapan yakni tahap persiapan, tahap sosialisasi, tahap pelatihan, tahap pendampingan dan tahap evaluasi. Metode yang digunakan berupa FGD forum group discussion), perencanaan partisipatif dan metode praktek. Hasil kegiatan ini memberi pemahaman pada masyarakat tentang pentingnya menjaga danau. Pemahaman masyarakat kelurahan Kayubulan tentang pengolahan eceng gondok menjadi biogas, briket, pupuk dan sedimen menjadi batako, batu bata dan pot tanaman meningkat secara keseluruhan hingga $48 \%$. Kegiatan ini berdampak positif pada peningkatan pengetahuan dan keterampilan kelompok Alata sebagai mitra sasaran.
\end{abstract}

Kata kunci : Pemberdayaan masyarakat, eceng gondok, sedimen

Abstract

The sedimentation rate of several rivers that empties into Limboto lake is getting higher than it started causing silting. The rapid growth of water hyacinths covering the surface of the lake causes changes in the lake ecosystem and financial losses for local fishermen. The Community Empowerment Learning Program (KKN PPM) in Kayubulan village aimed to educate the public through the implementation of water hyacinth and Limboto lake sediment processing technology. Community empowerment activities go through 5 (five) stages, namely the preparation stage, the socialization stage, the training stage, the mentoring stage and the evaluation stage. The methods used are in the form of FGD (forum group discussion), participatory planning and practical methods. The results of this activity gave people an understanding of the importance of protecting the lake. The understanding of the Kayubulan sub-district community about processing water hyacinth into biogas, briquettes, fertilizer and sediment into concrete blocks, bricks and plant pots increased by $48 \%$ overall. This activity had a positive impact on increasing the knowledge and skills of Alata's group as target partners.

Keywords: Community empowerment, water hyacinth, sediment 


\section{PENDAHULUAN}

Danau Limboto merupakan danau yang terbesar di provinsi Gorontalo yang berada di sebagian kelurahan Kayubulan Kabupaten Gorontalo. Kondisi danau Limboto sudah dalam keadaan kritis, luas dan kedalaman danau limboto semakin hari semakin berkurang. Salah satunya diakibatkan oleh proses sedimentasi yang menghasilkan lumpur sedimen. Pendangkalan dan penurunan luasan danau telah menurunkan fungsi ekosistem danau sebagai reservoir alami dan memicu pertumbuhan eceng gondok yang cepat. Mata pencarian masyarakat Kayubulan terdiri dari pengusaha, pegawai negeri, petani dan nelayan. Sebagian besar nelayan di kelurahan kayubulan menggantungkan hidupnya dari ikan yang hidup di danau Limboto. Namun kondisi ini menyebabkan ikan yang ada di danau Limboto semakin berkurang. Eceng gondok menutupi flora dan fauna yang ada di danau dari paparan sinar matahari dan menghambat terbentuknya oksigen di bawah permukaan air. Hal ini menyebabkan matinya ikan dan kerugian finansial bagi nelayan lokal (Hasim. H, 2018).

Eceng gondok banyak tumbuh di permukaan danau Limboto yang merupakan gulma air mengambang bebas yang tersusun dari lignin, selulosa dan hemiselulosa. Rata- rata produktivitas harian eceng gondok 0,26 ton biomassa kering per hektar di semua musim. Karena pertumbuhannya yang cepat dan ketahanan benihnya, eceng gondok telah menimbulkan banyak masalah di seluruh wilayah sungai. Hal ini menyebabkan eutrofikasi. Eutrofikasi merupakan peristiwa meningkatnya bahan organik dan nutrien(terutama unsur Nitrogen dan Phospor) yang terakumulasi di badan air. Eceng gondok telah menutupi permukaan danau Limboto sekitar 50-65\% dari total luas permukaan air danau ditutupi oleh eceng gondok. Kondisi ini menyebabkan penurunan kualitas ekosistem perairan. Disamping efek negatif dari tanaman eceng gondok, tanaman yang merupakan jenis gulma ini memiliki beberapa nilai ekonomis yang dapat dimanfaatkan. Diantara beberapa kemungkinan, yang paling menarik adalah produksi gas metana. Eceng gondok dapat dimanfaatkan dalam produksi biogas karena mempunyai kandungan hemiselulosa yang cukup besar dibandingkan komponen organik tunggal lainnya. Hemiselulosa adalah polisakarida kompleks yang merupakan campuran polimer yang jika dihidrolisis menghasilkan produk campuran turunan yang dapat diolah dengan metode anaerobic digestion untuk menghasilkan dua senyawa campuran sederhana berupa metana dan karbon dioksida yang biasa disebut biogas (Tangio. J, 2019).

Laju sedimentasi dari beberapa sungai yang bermuara di danau Limboto semakin tinggi sehingga menyebabkan pendangkalan. Batako dan bata merah dapat dibuat dari sedimen danau karena terdiri dari kapur, pasir dan lempung. Bata dari sedimen danau Limboto merupakan bahan bangunan alternatif untuk dinding bangunan dan dapat dijadikan salah satu inovasi produk di Indonesia.

Mitra sasaran adalah kelompok masyarakat pesisir danau Limboto kelurahan Kayubulan yang belum mempunyai usaha namun berkeinginan kuat untuk menjadi pengusaha yakni kelompok "Alata". Kelompok ini sudah pernah mencoba memproduksi beberapa produk dari eceng gondok seperti tas, sandal, tempat tissue. Kendala yang dihadapi adalah terbatasnya inovasi produk karena hanya bekerja ketika ada pesanan sehingga belum melihat potensi lain dari eceng gondok dan sedimen. Padahal potensi bahan berupa eceng gondok sangatlah banyak dan didepan mata. Kelompok ini akan diedukasi oleh 40 mahasiswa KKN PPM (Kuliah Kerja Nyata Pembelajaran 
Pemberdayaan Masyarakat) dengan memberikan bimbingan teknis untuk memanfaatkan teknologi pengolahan eceng gondok dan sedimen

Tujuan dari program pengabdian ini adalah 1] mengedukasi masyarakat pesisir danau di Kelurahan kayubulan tentang pentingnya menjaga lingkungan danau; 2] Sosialisasi pemanfaatan eceng gondok dan sedimen danau Limboto; 3] Mengimplementasikan teknologi pengolahan eceng gondok dan sedimen pada masyarakat kelurahan Kayubulan kecamatan Limboto kabupaten Gorontalo.

\section{BAHAN DAN METODE}

Pengabdian pada masyarakat di Kelurahan Kayubulan dilaksanakan selama 2 (dua) bulan oleh tim dosen pengabdi dan mahasiswa KKN PPM selama bulan Juli dan Agustus 2020 dengan sasaran yaitu kepada nelayan danau Limboto. Pelaksanaan program dilakukan 5 tahapan, yaitu:

a. Tahapan Persiapan

yaitu penentuan lokasi pelatihan, perhitungan jumlah peserta, penjadwalan kegiatan lanjutan, penyiapan materi pelatihan, desain modul, kuesioner, transport, peralatan seperti galon, pipa paralon, pencetak batako/batu bata , sekop, pisau, timbangan, ember, dan bahan- bahan seperti eceng gondok, sedimen, air, EM4 dan lain-lain

b. Tahapan Sosialisasi

tahapan ini meliputi edukasi dengan memberikan brosur/selebaran tentang pentingnya menjaga danau Limboto dari kepunahan dan sedimentasi, mengajak masyarakat untuk menanam pohon pelindung di sekitar danau, dan FGD (Forum Group Discussion) dengan pemerintah Kayubulan.

c. Tahapan Pelatihan

kelompok sasaran diberi pelatihan dengan 3 (tiga) metode yakni FGD, perencanaan partisipatif dan metode praktek yang berisi 4 materi yakni 1] Produk Eceng Gondok bernilai ekonomi 2] Pemanfaatan Eceng Gondok Danau Limboto menjadi Biogas dan Pupuk 3] Pengolahan sedimen Danau Limboto menjadi Batako dan Pot Tanaman, 4] Biobriket dari Eceng Gondok

d. Tahapan Pendampingan

pada tahapan ini mahasiswa KKN PPM melakukan pendampingan dengan metode praktek (bimtek) langsung ke masyarakat Kayubulan tentang implementasi teknologi pengolahan produk eceng gondok dan sedimen, misalnya pada peternak sapi dengan memberi bimbingan teknis langsung tentang cara mengolah kotoran sapi yang disubstitusi eceng gondok menjadi biogas dan pupuk. kuesioner juga dibagikan kepada masyarakat (129 kuesioner) untuk mengetahui tingkatan pengetahuan masyarakat tentang pemanfaatan eceng gondok dan sedimen danau Limboto.

e. Tahapan Evaluasi

pada tahapan ini tim pengabdi menilai pelaksanaan program pada kelompok sasaran dengan melakukan wawancara dan mengevaluasi hasil kuisioner masyarakat (129 sampel) tentang pengetahuan masyarakat tentang pemanfaatan eceng gondok dan sedimen danau Limboto. 
HASIL

Profil kependudukan Kelurahan Kayubulan pada tahun 2019 berjumlah 7.152 jiwa yang terbagi atas laki-laki 3.580 jiwa dan perempuan 3.572 jiwa. Mata pencarian masyarakat Kayubulan terdiri dari pengusaha, pegawai negeri, petani dan nelayan. Sebagian besar nelayan di kelurahan kayubulan menggantungkan hidupnya dari ikan yang hidup di danau Limboto (Dungga et al, 2018). Pemberdayaan masyarakat kelurahan Kayubulan melalui implementasi teknologi pengolahan eceng gondok dan sedimen danau Limboto. Hasil yang diperoleh dari kegiatan program pengabdian ini yakni terdiri dari beberapa tahap yakni 1] tahap persiapan menghasilkan bahan dan alat yang tersedia untuk kebutuhan sosialisasi dan pelatihan (gambar 1); 2] tahap sosialisasi menghasilkan suatu peningkatan pemahaman masyarakat tentang pentingnya menjaga kelestarian danau Limboto (gambar 2). Hasil ini dibuktikan dengan hasil kuesioner partisipasi masyarakat yang diambil dari 129 sampel yang mewakili masyarakat kelurahan Kayubulan; 3] tahap pelatihan dengan metode FGD menunjukkan tingkat partisipasi peserta pelatihan yang sebagian besar adalah nelayan dan peternak sapi. Metode praktek secara langsung kepada kelompok-kelompok ini memberi kesadaran untuk mengambil peluang ini dan menghasilkan suatu peningkatan pengetahuan masyarakat tentang teknologi pengolahan eceng gondok dan sedimen danau Limboto (gambar 3). Bukti adanya peningkatan pengetahuan masyarakat tercantum dalam hasil kuesioner (lampiran 1); 4] tahap pendampingan dan evaluasi menghasilkan suatu data hasil wawancara dan kuisioner (gambar 4). Penyebaran kuesioner kepada 129 masyarakat kelurahan Kayubulan dilakukan untuk mengetahui tingkat pemahaman masyarakat dengan total 20 (dua puluh) pertanyaan yang terdiri dari 4 soal tentang pemahaman kondisi danau limboto, 4 soal tentang biogas eceng gondok, 4 soal tentang briket eceng gondok, 4 soal tentang pupuk dari eceng gondok, dan 4 soal tentang pemanfaatan sedimen. Hasil secara keseluruhan dari 20 (dua puluh) pertanyaan menunjukkan bahwa pemahaman masyarakat tentang keseluruhan teknologi yang telah diedukasi dan diberikan pelatihan yakni $48 \%$ yang sudah memahami. Terjadi peningkatan pemahaman sebesar $48 \%$ menunjukkan hal yang baik.

Hasil 4 (empat) soal yang terdapat dalam kuesioner yang menunjukan tentang pemahaman masyarakat Kayubulan tentang kondisi danau Limboto saat ini. Sampel 129 orang yang telah mengisi kuesioner tersebut dengan persentase jumlah skor yang menjawab ya atau sudah paham sebesar $61 \%$ dari jumlah keseluruhan yang menjawab. Sedangkan sisanya 39\% adalah persentase jumlah skor yang menjawab tidak atau belum paham (tabel 1). Hal ini menunjukkan bahwa masyarakat sudah memahami bahwa pendangkalan danau Limboto disebabkan oleh sedimen. Sebagian sampel adalah nelayan di sekitar danau Limboto. Hasil kuesioner menunjukkan hasil bahwa para nelayan di kelurahan kayubulan memahami kondisi danau Limboto. Pengetahuan masyarakat tentang pemanfaatan eceng gondok menjadi biogas disajikan sebanyak empat soal. Sebanyak $46 \%$ masyarakat Kelurahan Kayubulan telah mengetahui dan paham terkait dengan pemanfaatan Eceng Gondok menjadi Biogas atau sebanyak 60 orang. Sedangkan masyarakat yang belum paham tentang pemanfaatan Eceng Gondok sebesar 54\% atau sekitar 69 orang (tabel 2). Untuk kuesioner tentang pengetahuan terkait pemanfaatan eceng gondok menjadi pupuk organik sebanyak empat soal menunjukkan 57 \% masyarakat di Kelurahan Kayu Bulan paham akan pemanfaatan eceng gondok dan $43 \%$ yang belum paham (tabel 3 ). Pemahaman masyarakat kelurahan Kayubulan tentang biobriket eceng gondok pada kuesioner sebanyak 4 (empat) soal 
dengan hasil yang menunjukkan persentase sebesar $36 \%$, sedangkan yang belum paham dengan persentase sebesar $64 \%$ (tabel 4). Hal ini terjadi karena istilah biobriket belum banyak didengar oleh masyarakat setempat yang terbiasa menggunakan gas untuk kebutuhan memasak. Hasil kuesioner pada pertanyaan tentang pemahaman masyarakat tentang manfaat sedimen menjadi batu bata dan media/pot tanaman sebanyak 4 (empat) soal menunjukkan persentase sebesar $42 \%$, sedangkan yang belum paham dengan persentase sebesar $58 \%$ (tabel 5 ).

\section{PEMBAHASAN}

Pemahaman masyarakat kelurahan Kayubulan tentang pengolahan eceng gondok menjadi biogas, biobriket, pupuk dan sedimen menjadi batako, batu bata dan pot tanaman terlihat dari hasil kuesioner meningkat secara keseluruhan sampai $48 \%$. Walaupun belum mencapai sesuai yang diinginkan namun materi pelatihan sudah membuat masyarakat pesisir danau paham bahwa eceng gondok dan sedimen dapat dimanfaatkan masyarakat dan berpotensi meningkatkan ekonomi masyarakat. Hasil wawancara dengan beberapa masyarakat sasaran anggota kelompok Alata menunjukan pemahaman terhadap materi pelatihan. Hal tersebut dibuktikan pada tahapan pendampingan kelompok ini secara langsung mempraktekkan hasil pelatihan. Penyebaran kuesioner kepada 129 masyarakat kelurahan Kayubulan yang dianggap mewakili masyarakat pesisir menunjukkan hasil yang baik. Meskipun pemahaman masyarakat tentang hal ini lebih rendah dibandingkan dengan pemahaman tentang produk biogas dan pupuk namun hal ini menjadi suatu ilmu yang bermanfaat yang bisa menjadi sumber alternatif bahan pembuat batako/batu bata.Walaupun belum mencapai sesuai yang diinginkan namun materi pelatihan sudah membuat masyarakat pesisir danau paham bahwa eceng gondok dan sedimen dapat dimanfaatkan masyarakat dan berpotensi meningkatkan ekonomi masyarakat. Eceng gondok merupakan tanaman air yang mempunyai laju pertumbuhan yang sangat cepat. Eceng gondok mengandung 95\% air dan menjadikannya terdiri dari jaringan yang berongga, mempunyai energi yang tinggi, terdiri dari bahan yang dapat difermentasikan dan berpotensi sangat besar dalam menghasilkan biogas (Chanakya, et al, 1993)

Pelatihan eceng gondok menjadi biogas menggunakan digester yang berjumlah 3 buah yang dijadikan tempat yang dapat mengolah eceng gondok sehingga menghasilkan energi biogas, kemudian ditambahkan starter, seperti kotoran sapi dan EM-4 (effective microorganisme-4) untuk mempercepat proses fermentasi. Setelah dilakukan fermentasi selama lebih dari satu bulan. Pembuatan biogas dari eceng gondok dengan cara fermentasi sehingga dapat digunakan sebagai pengganti bahan bakar khususnya minyak tanah atau gas dipergunakan oleh masyarakat untuk memasak. Keuntungan biogas ini adalah alat yang yang relatif sederhana sehingga biaya lebih murah. Produksi biogas di desain reaktor biogas sederhana dan menggunakan bahan dari eceng gondok dan campuran kotoran sapi, penambahan kotoran sapi berfungsi sebagai prekursor dan sumber mikroba penghancur eceng gondok. Api yang dihasilkan dari biogas eceng gondok berwarna biru dan cukup baik dengan kalor yang dihasilkan tidak terlalu besar pada suhu ruangan $\left(28^{\circ} \mathrm{C}\right)$. Hal ini menunjukan bahwa api yang dihasilkan dari biogas tersebut telah matang yang ditandai dengan api yang berwarna biru. Api yang dihasilkan dari biogas eceng gondok berwarna biru dan cukup baik dengan kalor yang dihasilkan tidak terlalu besar. Produksi biogas dari eceng gondok dan 
kotoran sapi diharapkan dapat memberikan kesadaran bagi masyarakat pentingnya pemanfaatan eceng gondok, dan secara tidak langsung mencegah pendangkalan danau limboto. Pemanfaatan eceng gondok diharapkan juga dapat memotivasi masyarakat yang ada disekitar danau Limboto.

Pelatihan tentang pemanfaatan sedimen menjadi batu bata, batako dan pot menunjukkan hasil pemahaman dan antusias masyarakat sasaran terhadap hal tersebut. Hal ini dibuktikan dengan adanya kelompok masyarakat yang secara langsung mempraktekkan teknologi yang didapatkan dari pelatihan tersebut. Bata merah dibuat dari sedimen danau Limboto karena terdiri dari kapur, pasir dan lempung. Bata dari sedimen merupakan bahan bangunan alternatif untuk dinding bangunan, bahan bangunan ini masih sedikit ada di Indonesia. bata lempung berupa blok-blok seperti bata merah, warnanya alami, proses pembuatannya tidak dibakar seperti pada bata merah, tetapi dicetak, dipadatkan dan dikeringkan dengan kondisi alam, sedangkan bahan dasar adalah sedimen, jenis bahan tambahan tergantung pada kebutuhan. berasal dari pelapukan dan pengendapan. Lempung adalah bahan mineral yang berbutir halus dengan ukuran kekasaran $<2$ mikron. Karena sifatnya yang halus dan ukuran kekasaran $<2$ mikron, dan proses pembuatanya yang tak melalui pembakaran inilah makanya lempung sangat mudah untuk dibuat dan langsung jadi yang kira kira hanya membutuhkan waktu 4 minggu. Tak perlu dibakar, tetapi dipanaskan dengan cara alami Kerusakan hanya mencapai sekitar 20 \%, karena pembakaran nya lebih merata Mempunyai tekstur dan warna yang alami (Kusdarto, 2006).

Pembuatan bata merah dan batako pada tahap pelatihan dilakukan dengan perbandingan variasi komposisi $35 \%$ pasir, sedimen $30 \%$ sedimen dan $35 \%$ semen, lalu variasi kedua $30 \%$ pasir, $40 \%$ sedimen, dan $30 \%$ semen. Hasil pembuatan bata merah dan batako pada kegiatan KKN PPM ini dilakukan pengujian kuat tekan di laboratorium Teknik Sipil (gambar ). Merujuk pada SNI 1974:2011 tentang cara uji tekan beton dengan benda uji silinder. Pengujian kuat tekan batako (masing-masing memiliki ukuran tinggi $15 \mathrm{~cm}$, panjang $29 \mathrm{~cm}$ dan tebal $10 \mathrm{~cm}$ ) dilakukan pada umur 3 hari kemudian disusun pada alat uji tekan. Sampel batako hasil pelatihan uji tekan beton dengan benda uji silinder, kekuatan nilai tekan belum memenuhi spesifikasi kuat tekan beton sesuai SNI 1974:2011 sedangkan sampel batu bata dari ketiga sampel yang diuji terdapat satu sampel yang memenuhi kuat tekan bata ringan dengan nilai 3,1 mpa dari nilai yang diijinkan yaitu 2,6 mpa. Hal ini menunjukkan bahwa sedimen danau Limboto berpotensi diolah menjadi batu bata.

\section{KESIMPULAN DAN SARAN}

Berdasarkan hasil kegiatan program KKN PPM secara bertahap tentang pengolahan eceng gondok dan sedimen, maka dapat disimpulkan bahwa program ini dapat memberi dampak positif pada masyarakat sasaran. Berbagai manfaat yang diperoleh yakni: 1] pengolahan eceng gondok dan sedimen berpotensi untuk pemberdayaan masyarakat kelurahan kayubulan; 2] pemahaman masyarakat terutama mitra sasaran di kelurahan Kayubulan meningkat. Hal ini terlihat dari antusias masyarakat pada tahap pelatihan dan pendampingan. Meskipun dari beberapa kuesioner menunjukkan sebagian masyarakat belum memahami tentang teknologi ini namun kelompok "Alata" yang menjadi mitra sasaran sudah mampu menguasai teknologi ini dan dapat secara berkesinambungan melatih masyarakat yang belum paham. 
Beberapa hal yang perlu disarankan adalah: 1] Program ini perlu ditindaklanjuti oleh pemerintah kelurahan Kayubulan dengan memfasilitasi kelompok Alata dalam produksi produk eceng gondok dan sedimen sehingga mampu menghasilkan secara ekonomi; 2] keberlanjutan program ini perlu didukung oleh stakeholders terkait.

\section{UCAPAN TERIMA KASIH}

Terima kasih diberikan kepada 1) Direktorat Riset dan Pengabdian Masyarakat (DRPM) Kemenristek-BRIN, 2) Pemerintah kelurahan Kayubulan, kelompok Alata, dan masyarakat kelurahan Kayubulan, 3) LPPM Universitas Negeri Gorontalo, 4) tim pengabdi, pelaksana dan mahasiswa peserta KKN PPM.

\section{DAFTAR PUSTAKA}

Chanakya, H.N., S. Borgaonkar, M. G. C. Rajan, dan M. Wahi. 1992. Two-Phase Anaerobic Digestion of Water Hyacinth or Urban Garbage. Bioresource Technology Vol. 42 Hal. 123-131 Elsevier Ltd.

Dungga, W. A., Sulila, I., \& Aneta, Y. (2018). Kabupaten Gorontalo. 24(2), 617-622.

Hasim, H. 2018. Perspektif Ekologi Politik Kebijakan Pengelolaan Danau Limboto. Publik (Jurnal IImu Administrasi), 7(1), 44. https://doi.org/10.31314/pjia.7.1.4452.2018

Tangio, J. 2019. Pemanfaatan biomassa enceng gondok dari danau Limboto sebagai penghasil biogas. Jambura journal of chemistry Volume 1(1):27-33 (http://ejurnal.ung.ac.id/index.php/jjc/article/view/2105)1.

Kusdarto, 2006. Prospek Pemanfaatan Endapan Lempung Danau Limboto Sebagai Bahan Baku Semen. Buletin Sumber Daya Geologi I(3):30-34. 


\section{LAMPIRAN}

Tabel 1. Hasil kuesioner tentang pengetahuan masyarakat Kayubulan tentang kondisi danau

\begin{tabular}{|c|c|c|}
\hline Pengetahuan & Presentase & Jumlah Sampel \\
\hline Paham & $61 \%$ & 78 orang \\
\hline Belum Paham & $39 \%$ & 51 orang \\
\hline Total & $100 \%$ & 129 orang \\
\hline
\end{tabular}

Tabel 2. Hasil kuisioner tentang pengetahuan masyarakat Kayubulan tentang pemanfaatan eceng gondok menjadi biogas

\begin{tabular}{|c|c|c|}
\hline Pengetahuan & Presentase & Jumlah Sampel \\
\hline Paham & $46 \%$ & 60 orang \\
\hline Belum Paham & $54 \%$ & 69 orang \\
\hline Total & $100 \%$ & 129 orang \\
\hline
\end{tabular}

Tabel 3. Hasil kuesioner tentang pengetahuan masyarakat Kayubulan tentang pemanfaatan eceng gondok menjadi pupuk organik

\begin{tabular}{|c|c|c|}
\hline Pengetahuan & Presentase & Jumlah Sampel \\
\hline Paham & $57 \%$ & 73 orang \\
\hline Belum Paham & $43 \%$ & 56 orang \\
\hline Total & $100 \%$ & 129 orang \\
\hline
\end{tabular}


Tabel 4. Hasil kuesioner tentang pengetahuan masyarakat Kayubulan tentang pemanfaatan eceng gondok menjadi biobriket

\begin{tabular}{|c|c|c|}
\hline Pengetahuan & Presentase & Jumlah Sampel \\
\hline Paham & $36 \%$ & 46 orang \\
\hline Belum Paham & $64 \%$ & 83 orang \\
\hline Total & $100 \%$ & 129 orang \\
\hline
\end{tabular}

Tabel 3. Hasil kuesioner tentang pengetahuan masyarakat Kayubulan tentang pemanfaatan sedimen menjadi batu bata

\begin{tabular}{|c|c|c|}
\hline Pengetahuan & Presentase & Jumlah Sampel \\
\hline Paham & $42 \%$ & 54 orang \\
\hline Belum Paham & $58 \%$ & 75 orang \\
\hline Total & $100 \%$ & 129 orang \\
\hline
\end{tabular}




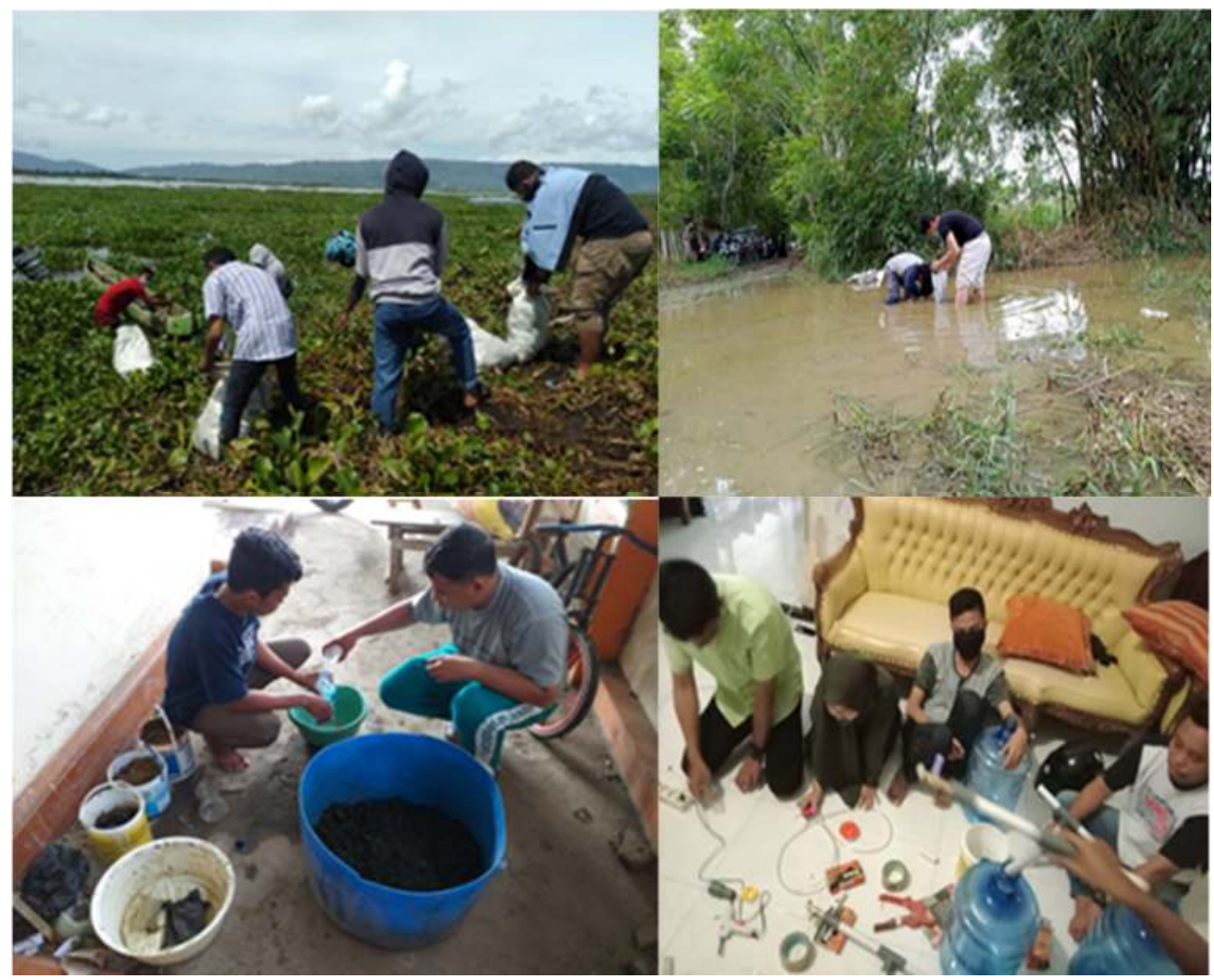

Sumber: Dokumentasi KKN PPM

Gambar 1. Tahap persiapan alat dan bahan eceng gondok dan sedimen

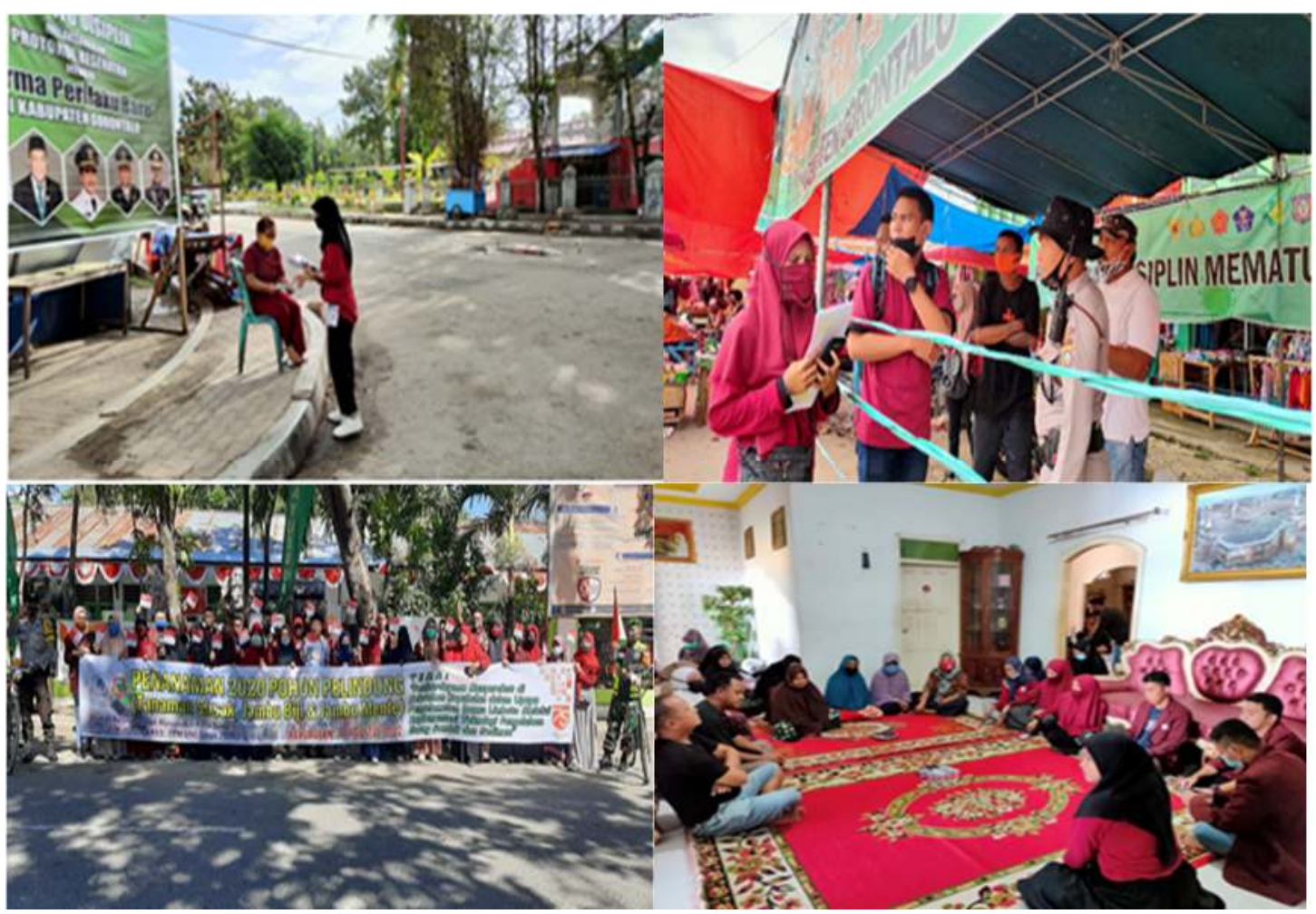

Gambar 2. Tahap sosialisasi 

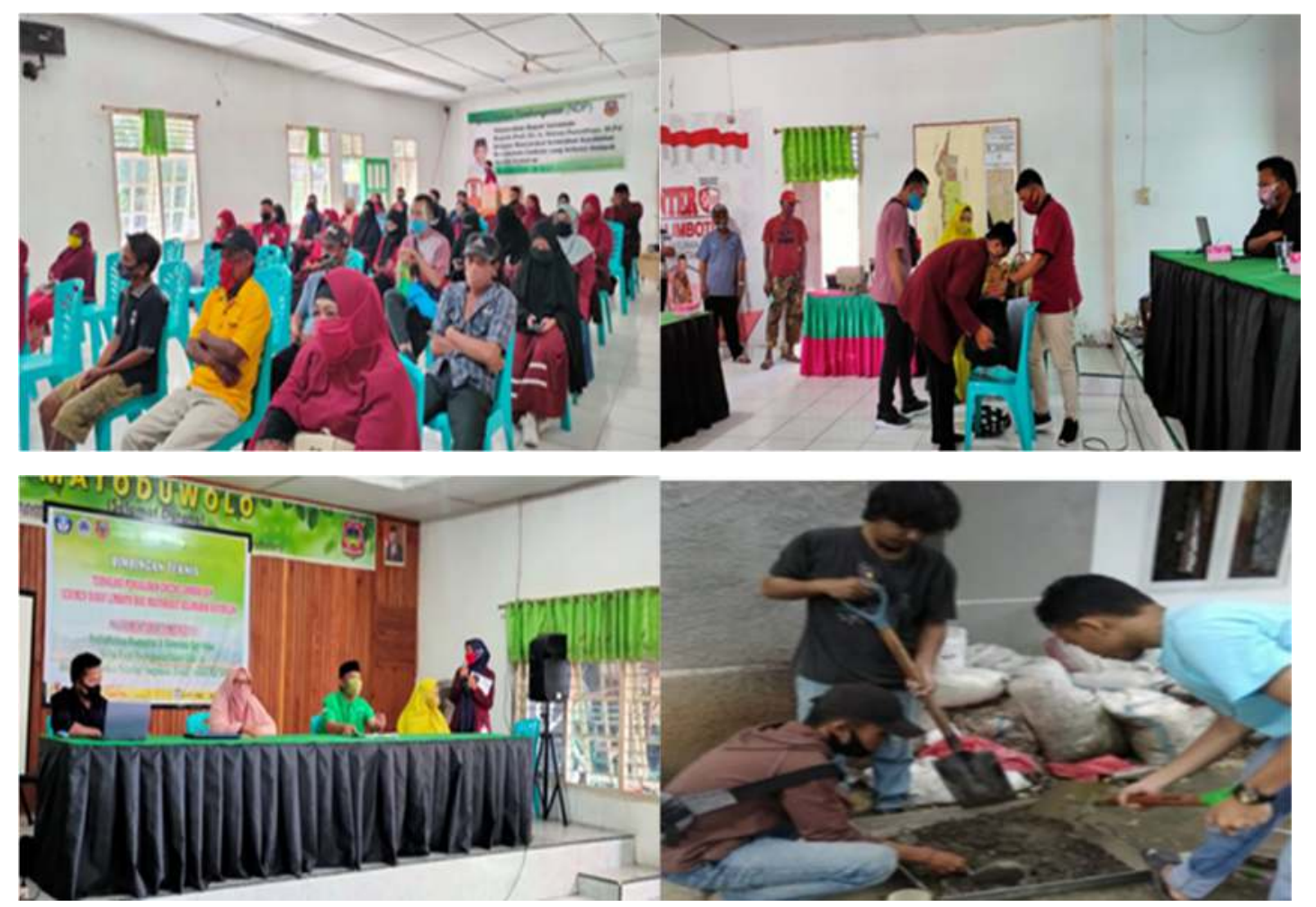

Gambar 3. Tahap pelatihan 

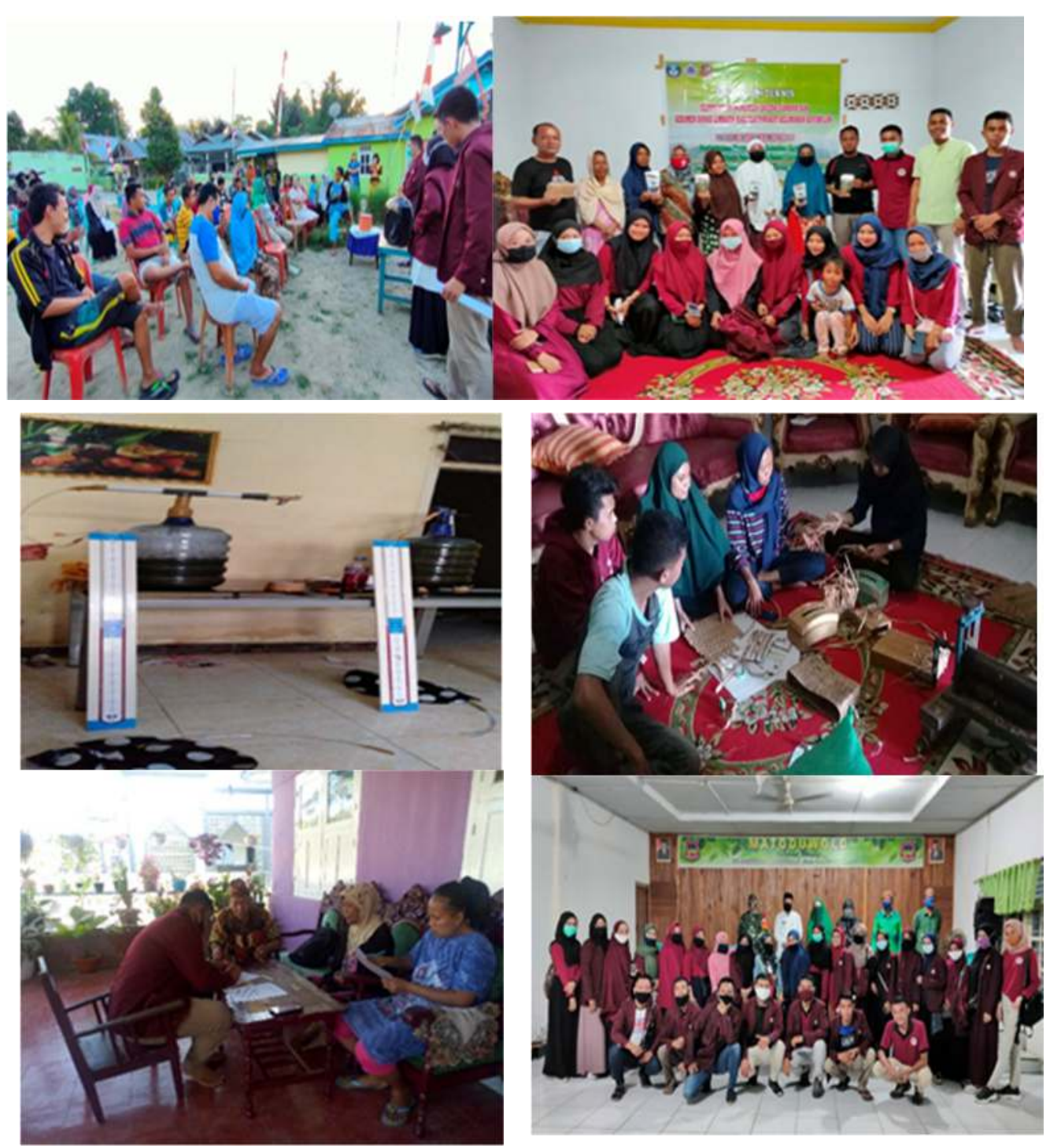

Gambar 4. Tahap pendampingan dan evaluasi 